\title{
Medische professionaliteit in de geneeskunde opleiding
}

\begin{abstract}
Alle opleidingen, zowel de basis- als de medisch specialistische vervolgopleidingen, zitten midden in een ingrijpend veranderingsproces. In de basisopleiding zijn nieuwe curricula ontworpen waarin onderwijs gerelateerd aan een ziektegeschiedenis of probleem wordt aangeboden, preklinische en klinische vakken geïntegreerd aan bod komen, onderwijs in kleine groepen wordt gegeven, en veel aandacht wordt geschonken aan communicatieve vaardigheden en attitude. Daarnaast zijn competentiegericht opleiden op dit moment door de ervaringen op middelbare scholen en in het MBO helaas een beetje een beladen term - academische vorming, reflectie van de student op de eigen vorderingen en feedback van de begeleiders wezenlijke kenmerken van de opleiding geworden. Deze ontwikkelingen sluiten aan bij de nieuwe programmering van de medisch specialistische vervolgopleidingen zoals die door het Centraal College Medische Specialismen wordt gevraagd. ${ }^{1}$ Langzaam maar zeker ontstaat daarmee in veel opzichten een medisch opleidingscontinuüm van basisopleiding, specialistenopleiding en bij- en nascholing. De ontwikkeling van medische professionaliteit is daarbij één van de hoekstenen van het opleidingscontinuüm geworden.
\end{abstract}

Het concept van competentiegericht leren in de geneeskunde opleiding is overgewaaid uit Canada. Daar heeft de beroepsgroep het zogenaamde CanMEDS 2000 competentiemodel ontwikkeld. ${ }^{2}$ Volgens dit model vervult de goede arts zeven rol- len. De medical expert is de deskundige die effectieve en ethisch verantwoorde patiëntenzorg biedt. De communicator is in staat tot een goede communicatie met de patiënt en zijn of haar omgeving. De collaborator werkt goed samen met collegae en andere zorgverleners. De manager werkt effectief en efficiënt en vindt een goede balans tussen werk en persoonlijke ontwikkeling. De health advocate functioneert goed binnen de gezondheidszorg in brede, maatschappelijke zin en gaat adequaat om met fouten in de zorg. De vertaling van de scholar is interessant omdat dat enerzijds de rol is van degene die zelf leert en bijschoolt en anderzijds de rol is van de docent die anderen schoolt. En tenslotte, de professional handelt volgens de standaard van de beroepsgroep, maar kent ook de grenzen van zijn eigen kunnen en handelt daarnaar.

De wezenlijke vraag hierbij is hoe je een student en aios (arts in opleiding tot specialist) kunt opleiden zodat deze een expert is in al deze zeven rollen. En toegespitst op de medische professionaliteit, hoe leid je iemand op zodat hij/zij daarover beschikt en een goede dokter wordt? Hierbij moeten we ons realiseren dat verschillende aspecten van zo'n goede opleiding ook nu al in de opleiding aanwezig zijn. Het is dus zeker niet zo dat het tot nu toe 'niet goed' was, maar het kan wel 'beter'.

In de klassieke oudheid was de dokter een godheid en werd de geneeskunde uitgeoefend in de tempel. Eerst in het oude Egypte waar omstreeks 2900 voor Chris- 
tus Imhotep, priester-arts aan het hof van koning Zoser, door de Egyptenaren vereerd werd als god van de geneeskunde. . $^{3-4}$ Vele eeuwen later, tijdens de Griekse beschaving, ontstond de Asklepios cultus. De priesters van de Asklepios tempels kenden weliswaar niet de oorzaak, maar zij meenden wel het verloop van ziektes te kennen. Deze kennis werd door hen van generatie op generatie overgedragen. Maar zelfs ten tijde van het zich verspreidende christendom waren het tot ver in de middeleeuwen priesters en monniken die de taak van geneesheer uitoefenden en hun kennis van leermeester aan leerling overdroegen. Na die tijd ontstond het besef dat voor een goede artsopleiding 'algemene ontwikkeling' nodig was. De 'artes liberales', de vrije kunsten, vormden de basis van de opleiding omdat men meende dat die nodig was om medische vragen te kunnen analyseren en begrijpen. ${ }^{5}$ Het concept dat de vrije kunsten belangrijke voorwaarde zijn voor de goede dokter, werd in de zeventiende eeuw weer verlaten en maakte plaats voor het besef dat kennis over gezondheid en ziekte gebaseerd dient te zijn op wat we nu basisvakken noemen zoals anatomie, biochemie, fysiologie en pathologie. Voor het huidige concept van de goede dokter en de goede opleiding leveren de drie elkaar in de tijd gevolgde ontwikkelingen elk een bijdrage daaraan: van de aanvankelijk aan priesters voorbehouden meester-gezel scholing, via de vrije kunsten naar uiteindelijk de basisvakken en medisch-technologische ontwikkelingen als hoekstenen van de opleiding.

Een aantal jaren geleden vroeg de redactie van de British Medical Journal aan haar lezers 'wat maakt iemand tot een goede dokter?' De vraag leverde vele reacties op, niet alleen van dokters, maar ook van patiënten. ${ }^{6} \mathrm{Bij}$ de antwoorden zien we karakteristieken die zo uit het hierboven genoemde CanMEDS competentiemodel gehaald hadden kunnen worden. Zelfs de minder voorspelbare karakteristieken zoals moed, creativiteit en optimisme kunnen hieronder worden gerubriceerd. Eén reactie van een lezer van de British Medical Journal was opmerkelijk. Deze lezer plaatste de vraag wat een goede dokter is, in het licht van de beroemde woorden boven de ingang van de Apollo tempel in Delphi "ГN $\Omega \Theta I$ I $\Sigma$ EAYTON" (Ken uzelve) en stelde vast dat de goede dokter niet bestaat, net zoals de goede mens niet bestaat. Iedere dokter die zichzelf kent, weet dat hij af en toe gedachten en gevoelens heeft die 'niet-goed' zijn. Hij stelt dan ook voor om te spreken van de 'goed-genoege dokter'. ${ }^{7}$

In april jl. presenteerde de KNMG het Manifest Medische professionaliteit. ${ }^{8}$ Hierin stelt de KNMG dat medische professionaliteit de basis is voor het 'contract' tussen arts en samenleving. Centraal hierbij staat de vraag hoe arts en samenleving het begrip 'medisch professionele autonomie' invullen. Het manifest stelt dat medische professionaliteit van artsen vereist dat zij hun verantwoordelijkheid voor kwalitatief goede zorg nemen, verantwoordelijkheden delen met andere hulpverleners én verantwoording afleggen over hun handelen. Hiermee 'verdienen' artsen hun professionele autonomie, ofwel de ruimte om naar beste kunnen de individuele patiënt de beste zorg te leveren. Nog recenter besteedde de redactie van Academic Medicine het volledige november 2007 nummer aan medische professionaliteit. ${ }^{9}$ In verschillende artikelen komt aan de orde hoe je bewuste aandacht voor medische professionaliteit in onderwijs- en opleidingsprogramma's kunt vormgeven, hoe je cultuurveranderingen binnen instellingen (geneeskunde faculteiten, UMC's, opleidingsziekenhui- 
zen) kunt stimuleren en hoe bewustwording van de individuele verantwoordelijkheid van spelers in de gezondheidszorg en -organisaties (rolmodellen) verbeterd kan worden. Interessant is daarbij dat naast vakinhoudelijke en medisch-technische aspecten van het vak academische en 'algemene ontwikkelingsvaardigheden' steeds meer een onderscheiden bijdrage leveren aan medische professionaliteit. Hierbij ontstaat bewust ruimte voor andere kwaliteiten dan uitsluitend de doelgerichte vakbekwaamheid. Deze roep om brede vorming wordt ook in andere vakgebieden dan de geneeskunde steeds meer gehoord. ${ }^{10}$ Ofschoon de context van de artikelen in Academic Medicine die van de Verenigde Staten is, zijn ze ook voor ons in Nederland en Vlaanderen inspirerend en kunnen ze bijdragen aan hoe wij medische professionaliteit als één van de competenties van de arts en medisch specialist kunnen vormgeven.

Tot slot van dit Redactioneel een aantal praktische punten. Binnen de redactie van het TMO hebben zich enkele veranderingen voorgedaan. In de loop van 2007 hebben we afscheid genomen van Hannah Verbeek als redactiesecretaris. Hannah heeft deze functie vanaf 2003 vervuld en was daarbij niet alleen een centrale persoon binnen de redactie, maar heeft een belangrijke invloed gehad op de huidige vormgeving van het TMO. Door de komst van Geertje Karsten-van der Giessen als redactiesecretaris is het secretariaat naar het UMC Groningen verhuisd, dat vanaf 1 januari jl. ook de nieuwe thuishaven van de hoofdredacteur is geworden. Verder hebben we eind 2007 afscheid genomen van dr. Janke Cohen-Schotanus en drs. Lia Fluit die respectievelijk vanaf 2001 en 2003 lid waren van de redactie. Zij zijn opgevolgd door prof. dr. Onno Terpstra (Leiden) en dr. Peter Boendermaker (Gronin- gen). De redactie wil Hannah, Janke en Lia bedanken voor hun grote inzet voor het TMO en natuurlijk de nieuwe redactieleden welkom heten.

Een belangrijke ontwikkeling is dat het bestuur van de NVMO een afspraak heeft gemaakt met de hoofdredactie van Medical Teacher waarbij Medical Teacher twee keer per jaar een manuscript zal publiceren waarbij het NVMO-bestuur en de TMO-redactie gezamenlijk verantwoordelijk zijn voor de beoordelingsprocedure. De werkgroepen van de NVMO zullen worden uitgenodigd een artikel voor hun rekening te nemen. Het is de bedoeling dat het artikel dan tevens in het TMO wordt gepubliceerd.

Ik hoop dat deze $27^{\text {ste }}$ jaargang van het Tijdschrift voor Medisch Onderwijs voor zowel lezers als auteurs interessante en inspirerende artikelen zal opleveren en dat het tijdschrift daarmee door de vele professionals in de gezondheidszorg intensief als discussie- en ontwikkelplatform zal worden gebruikt.

\section{Jan Borleffs}

\section{Literatuur}

1. Bleker OP, Hoorntje JCA, Schelfhout VJ. Beter en leuker, CCMS ontvouwt plannen voor de vervolgopleiding van medisch specialisten. Medisch Contact 2004;59:1692-5.

2. Frank JR, Jabbour M, Tugwell P et al. Skills for the new millennium. Report of the societal needs working group, CanMEDS 2000 project. Ann R Coll Physicians Surg Can 1996;29:206-16.

3. Lindeboom GA (7e druk door M.J. van Lieburg bewerkt). Inleiding tot de geschiedenis der geneeskunde. Rotterdam: Erasmus Publishing; 1993.

4. Molenaar J. De goede dokter. Utrecht: Van der Wees uitgeverij; 1999.

5. Burns CR. The humanities and modern medical education. In (Kerkhoff AHM, Luyendijk-Elshout AM, Poulissen MJD, eds.) De novis Inventis. Essays in the history of medicine. Amsterdam: Holland University Press; 1984.

6. Letters (What's a good doctor and how do you make one). BMJ 2002;325:711-16. 
7. Holmes J. Good doctor, bad doctor. A psychodynamic approach. BMJ 2002;325:722.

8. Koninklijke Maatschappij ter Bevordering der Geneeskunst. KNMG Manifest Medische professionaliteit. Utrecht; 2007.

9. Professionalism. Acad Med 2007;82:1009-1108.

10. Oostrom F van. Markt en ziel, jaarrede voor de Verenigde Vergadering van de Koninklijke Nederlandse Akademie van Wetenschappen op 21 mei 2007; Amsterdam, 2007. 